\title{
Fluktuasi Populasi Lalat Buah Bactrocera spp. (Diptera : Tephritidae) pada Pertanaman Cabai Merah (Capsicum Annuum) di Kabupaten Bandung, Jawa Barat
}

\author{
Agus Susanto ${ }^{1}$, Yadi Supriyadi ${ }^{1}$, Tohidin ${ }^{1}$, Nenet Susniahti ${ }^{1}$, dan Vickri Hafizh ${ }^{2}$ \\ ${ }^{1}$ Departemen Hama dan Penyakit Tumbuhan, Fakultas Pertanian, Universitas Padjadjaran Kampus \\ Jatinangor 45363 \\ ${ }^{2}$ Alumnus Program Studi Agroteknologi, Fakultas Pertanian, Universitas Padjadjaran \\ Alamat korespondensi: a.susanto@unpad.ac.id
}

\begin{abstract}
Fluctuation population of fruit flies Batrocera spp. (Dipthera: Tephritidae) on chilli (Capsicum annuum) plantation areas in Bandung Regency, West Java
\end{abstract}

Fruit flies (Bactrocera spp.) are destructive pest that cause damages to horticulture commodities such as fruits and vegetables. The purpose of this study was to investigate fluctuation population of fruit flies in relation to abiotic factors, such as temperature, rainfall, number of rainy days, and biotic factors, such as host phenology and natural enemies. The field experiment was conducted in Pulosari Village, Pangalengan, Bandung. This research used survey method by placing 20 fruit flies traps on host plants, in which 10 traps were being placed in the outside and the others were being placed in the inside within 10 meters distance per trap. Trapped flies were collected and their population was counted in every week. The results revealed that abiotitic factors (temperature, rainfall, number of rainy days) have non significant influence indicated by the regression analysis of each temperature $\left(Y=-101.2+2298.7 x ; R^{2}=0.253 ; P>0.05\right)$, rainfall $\left(Y=0.143+154.4 x ; R^{2}=0.004\right.$; $\mathrm{P}>0.05)$, and the number of rainy days $\left(\mathrm{Y}=6.607+140.51 \mathrm{x} ; \mathrm{R}^{2}=0.015 ; \mathrm{P}>0.05\right)$. Meanwhile, fruit fly with the dominant population was Bactocera dorsalis which was included into sibling species of Bactrocera dorsalis Complex with number of population was $93 \%$ from specimen sample.

Keywords: Fluctuation population, fruit flies, Batrocera dorsalis Complex, Chilli

\begin{abstract}
ABSTRAK
Lalat buah (Bactrocera spp.) merupakan hama penting yang menyerang tanaman hortikultura baik buah-buahan ataupun sayuran buah. Penelitian ini bertujuan untuk mengetahui korelasi fluktuasi populasi lalat buah pada pertanaman cabai merah terhadap faktor abiotik berupa suhu, curah hujan, jumlah hari hujan dan faktor biotik berupa fenologi tanaman inang dan musuh alami. Percobaan ini dilaksanakan di Desa Pulosari, Kecamatan Pangalengan Kabupaten Bandung. Percobaan dilakukan menggunakan metode survei dengan memasang perangkap lalat buah pada lahan pertanaman cabai merah sebanyak 20 perangkap dengan 10 perangkap bagian luar dan 10 perangkap bagian dalam dengan jarak antar perangkap 10 meter. Hasil tangkapan dikumpulkan dan dihitung populasi lalat buah yang terperangkap setiap minggunya. Hasil penelitian menunjukan faktor abiotik (suhu, curah hujan, jumlah hari hujan) tidak memberikan pengaruh signifikan ditunjukan dengan analisis regresi masing-masing pada suhu ( $Y=-101,2+2298,7 x$; $\mathrm{R} 2=0,253 ; \mathrm{P}>0,05)$, Curah hujan $(\mathrm{Y}=0,143+154,4 \mathrm{x} ; \mathrm{R} 2=0,004 ; \mathrm{P}>0,05)$, dan Jumlah hari hujan $(\mathrm{Y}=6,607+140,51 \mathrm{x} ; \mathrm{R} 2=0,015 ; \mathrm{P}>0,05)$ Sedangkan lalat buah yang memiliki populasi paling dominan adalah Bactrocera dorsalis yang termasuk sibling dari spesies Bactrocera dorsalis Kompleks dengan jumlah populasi sebanyak 93\% dari sampel spesimen.
\end{abstract}

Kata kunci : Fluktuasi populasi, Lalat buah, Bactrocera dorsalis Kompleks, Cabai merah 


\section{PENDAHULUAN}

Cabai merah (Capsicum annuum L.) merupakan salah satu komoditas sayuran yang sangat penting bagi masyarakat Indonesia. Cabai merah merupakan sayuran yang memiliki banyak kegunaan. Selain dikonsumsi sebagai bahan olahan masakan sehari-hari, cabai merah juga digunakan sebagai bahan baku industri seperti industri makanan dan obat-obatan karena dalam cabai merah banyak mengandung zat-zat yang dibutuhkan oleh tubuh seperti vitamin, mineral, zat besi, kalium, kalsium, fosfor, dan niasin (Patty, 2012). Pada budidaya cabai merah banyak faktor yang menyebabkan rendahnya produktivitas. Salah satu faktor yang membuat rendahnya produktivitas cabai merah adalah serangan hama dan penyakit tanaman. Lalat buah merupakan salah satu hama penting bagi tanaman cabai merah (Anonim, 2009). Pada tanaman cabai merah rata-rata tingkat serangan lalat buah bisa mencapai 20-25\% (Wardani dan Purwanta, 2008).

Lalat buah (Bactrocera spp.) merupakan hama penting yang menyerang tanaman holtikultura baik buah-buahan ataupun sayuran buah pada umumnya, namun tidak semua jenis lalat buah berperan sebagai hama yang merugikan. Secara keseluruhan hanya kira-kira $10 \%$ yang merupakan hama. Sebagai contoh, di daerah Indo-Pasifik dilaporkan terdapat 800 spesies lalat buah, tetapi hanya 60 spesies yang merupakan hama penting (White \& Elson-Harris., 1992 dikutip Susanto, 2010b). Keseluruhan spesies yang ada, hanya kurang dari lima spesies merupakan hama yang merugikan, salah satu diantaranya adalah Bactrocera dorsalis Kompleks yang banyak menimbulkan kerusakan pada buah-buahan seperti belimbing, mangga, jeruk dan cabai merah sehingga bila tanpa pengendalian, serangannya sering menimbulkan gagal panen (Kalshoven, 1981).

Menurut Ye et al., (2007), fluktuasi populasi lalat buah terjadi karena faktor iklim (abiotik) berupa suhu, curah hujan, jumlah hari hujan, kelembaban, dan sinar matahari. Faktor suhu dan kelembaban dapat memengaruhi fluktuasi populasi lalat buah di lapangan, karena dapat memengaruhi perkembangan dan reproduksi lalat buah. Sedangkan curah hujan dan jumlah hari hujan yang tinggi dapat menyebabkan populasi lalat buah meningkat (Herlinda dkk., 2008).

Faktor biotik berupa fenologi tanaman inang, potensi inang lain, serta musuh alami juga berperan terhadap fluktuasi populasi lalat buah pada lahan pertanaman. Faktor inang merupakan faktor utama lain yang mempengaruhi fluktuasi lalat buah di lahan (Ye and Liu, 2005). Lalat buah merupakan hama yang sifatnya polifag, sehingga mempunyai banyak inang lain selain inang yang utama (Piay dkk., 2010). Lalat buah yang menyerang buahbuahan musiman, akan mempunyai fluktuasi populasi yang beragam dan erat hubungannya dengan keberadaan buah dari inang tersebut (Ginting, 2009).

Menurut Messenger (1976) dikutip Siwi (2005), bahwa aktivitas lalat buah seperti kawin dan peletakkan telur pada inang dipengaruhi oleh keadaan iklim. Lalat buah dapat dengan mudah memanifestasikan pola infestasi yang berbeda beda yang sesuai dengan geografi lokal dan iklim (Ye, 2001). Pada umumnya populasi lalat buah akan meningkat seiring dengan peningkatan curah hujan. Karena kemungkinan curah hujan memiliki hubungan terhadap pembuahan tanaman inang dan masa pembuahan banyak terjadi ketika sering hujan (Allwood, 1997). Selain itu faktor suhu juga berpengaruh terhadap perkembangan populasi, lama hidup serta mortalitas lalat buah dikarenakan lalat buah dapat hidup dan berkembang pada suhu 10-30 C dan pada suhu antara $25-30^{\circ} \mathrm{C}$ telur lalat buah dapat menetas dalam waktu yang relatif singkat yaitu 30-36 jam. (Bateman, 1972 dikutip Ginting, 2009).

Ketersediaan buah sebagai inang serta peranan musuh alami juga berpengaruh terhadap jumlah populasi lalat buah pada suatu wilayah tertentu. Aktivitas lalat buah dalam menemukan tanaman inang ditentukan oleh warna dan aroma dari buah inang. Semakin banyak ketersediaan inang cabai merah di lahan maka semakin besar kemungkinan meningkatnya populasi lalat buah pada tanaman tersebut. Hal ini dikarenakan lalat buah menggunakan sejumlah isyarat visual ataupun isyarat kimia untuk menemukan inang berupa buah atau sayuran (Sunarto, 2011). Peranan musuh alami berupa predator dan parasitoid juga berpengaruh terhadap populasi lalat buah di lahan. Populasi musuh alami tersebut dipengaruhi oleh umur tanaman dan ketersediaan inang di lapangan. Tingginya populasi musuh alami lalat buah pada saat ketersediaan lalat buah meningkat sehingga populasi parasitoid juga meningkat (Herlinda dkk., 2007).

Hasil dari penelitian ini diharapkan dapat memberikan informasi data ilmiah mengenai 
fluktuasi populasi lalat buah pada pertanaman cabai merah serta memberikan pemahaman terhadap bioekologi lalat buah, agar dapat menunjang strategi pengendalian yang tepat terhadap hama lalat buah pada pertanian komoditas cabai merah.

\section{BAHAN DAN METODE}

Percobaan dilakukan di Desa Pulosari, Kecamatan Pangalengan Kabupaten Bandung dengan ketinggian 1.445,97 meter diatas permukaan laut (mdpl) (Anonim, 2011). Identifikasi hama lalat buah yang terperangkap dilakukan di Laboratoriun Hama Tanaman, Departemen Hama dan Penyakit Tumbuhan, Fakultas Pertanian, Universitas Padjadjaran.

Penelitian dilakukan pada tanaman cabai merah produktif. Percobaan ini dilakukan menggunakan metode survei dengan memasang perangkap lalat buah pada lahan pertanaman cabai merah sebanyak 20 perangkap dengan jarak antar perangkap 10 meter. Hasil tangkapan dikumpukan dan dihitung populasi lalat buah yang terperangkap tiap minggunya. Kemudian dilakukan analisis regresi dengan menghubungkan sebab-akibat antara satu variabel dengan variabel yang lain. Penelitian ini menggabungkan fluktuasi populasi lalat buah serta korelasinya terhadap pengaruh cuaca (curah hujan, suhu udara, dan jumlah hari hujan) serta fenologi tanaman cabai merah dan musuh alami.

\section{Peubah yang Diamati}

Pengamatan dilakukan 1 kali seminggu selama 3 bulan dari awal pemasangan perangkap pada tanaman fase pembungaan sampai dengan panen. Pengambilan data diambil data sebanyak 12 kali pengamatan. Parameter yang diamati selama penelitian ini berlangsung berupa :

1. Fluktuasi populasi lalat buah pada pertanaman cabai merah

2. Jenis lalat buah yang tertangkap

3. Suhu udara, curah hujan, dan jumlah hari hujan

4. Fenologi tanaman cabai merah

5. Bioekologi musuh alami lalat buah

6. Pola aktivitas harian

Identifikasi yang dilakukan berupa menghitung jumlah dan mengamati spesies (jenis) lalat buah yang terperangkap kemudian melihat morfologi lalat buah di bawah mikroskop meliputi bentuk caput, thoraks, abdomen, sayap, panjang alat kelamin, maupun warna pada spesimen lalat buah yang didapat. Identifikasi terhadap musuh alami pada lalat buah berupa predator dilakukan dengan cara mendata dan mengambil sampel predator lalat buah yang ditemukan di lahan dan parasitoid juga yang memarasit larva lalat buah yang terdapat dalam wadah rearing. kemudian identifikasi dilakukan berdasarkan morfologi serangga musuh alami tersebut.

Data yang diperoleh dari hasil penelitian ini dianalisis dengan menggunakan program software SPSS 17 yang meliputi analisis regresi dan korelasi parametrik pearson. Data yang dianlisis yaitu hubungan antara fluktuasi populasi lalat buah dengan kondisi cuaca berupa suhu, curah hujan, jumlah hari hujan.

Hubungan antara jumlah populasi lalat buah yang tertangkap dengan faktor abiotik dianalisis menggunakan model regresi linier sederhana menurut Gasperz (1991) sebagai berikut:

$$
\begin{aligned}
& \mathrm{Y}=\beta_{0}+\beta_{1} \mathrm{X}+\varepsilon \\
& \hat{\mathrm{Y}}=\mathrm{a}+\mathrm{bX}
\end{aligned}
$$

\section{HASIL DAN PEMBAHASAN}

\section{Fluktuasi Populasi Lalat buah (Bactrocera spp.)}

Data pada Tabel 1 menunjukkan populasi yang beragam pada setiap minggunya. Naik atau turunnya populasi lalat buah yang terdapat pada suatu pertanaman dapat dipengaruhi oleh faktorfaktor pendukungnya seperti faktor abiotik dan faktor biotik. Perubahan kelimpahan populasi lalat buah erat kaitannya dengan keadaan faktor lingkungan biotik dan abiotik dimana lalat buah tersebut hidup (Chen et al., 2006).

Hasil pengamatan populasi lalat buah pada 3 minggu di awal pengamatan populasi lalat buah tertinggi mencapai 243 ekor pada perangkap luar dan 135 ekor lalat buah pada perangkap dalam (Tabel 1). Hasil tangkapan lalat buah pada usia 9 MST tersebut cendrung meningkat di bandingkan dengan 2 minggu hasil tangkapan sebelumnya pada usia 7 MST dan 8 MST yang cenderung menurun. Peningkatan jumlah populasi di pengamatan awal tersebut karena masuknya lalat buah yang menyerang inang lain berupa pertanaman cabai merah dan tomat yang berada di sekitar lokasi pengamatan (Herlinda dkk., 2008). Lalat buah dari luar tersebut tertarik dengan aroma yang dikeluarkan metil eugenol yang dipasang pada perangkap. 
Tabel 1. Pengaruh cuaca (suhu, curah hujan, jumlah hari hujan) terhadap hasil tangkapan perangkap lalat buah di Desa Pulosari Pangalengan.

\begin{tabular}{|c|c|c|c|c|c|c|}
\hline $\begin{array}{c}\text { Usia } \\
\text { Tanaman }\end{array}$ & $\begin{array}{c}\text { Perangliap } \\
\text { luar } \\
\text { (elior) }\end{array}$ & $\begin{array}{c}\text { Peranglicap } \\
\text { dalam } \\
\text { (elior) }\end{array}$ & $\begin{array}{c}\text { Jumlah } \\
\text { tangliapan } \\
\text { (elior) }\end{array}$ & $\begin{array}{c}\text { Suhu } \\
\text { rata-rata } \\
\text { ("C) }\end{array}$ & $\underset{\text { hujan }(\mathrm{mm})}{\text { Curah }}$ & $\underset{\text { bujan }}{\text { Jumlah har }}$ \\
\hline $7 \mathrm{MST}$ & 197 & 117 & 314 & 20,5 & 80 & 6 \\
\hline $8 \mathrm{MST}$ & 118 & 45 & 163 & 20,5 & 7 & 1 \\
\hline 9 MST & 243 & 135 & 378 & 20,9 & 24 & 3 \\
\hline $10 \mathrm{MST}$ & 133 & 100 & 233 & 20,8 & 143 & 5 \\
\hline $11 \mathrm{MST}$ & 75 & 52 & 127 & 21,1 & 25 & 1 \\
\hline 12 MST & 65 & 42 & 107 & 21,2 & 15 & 2 \\
\hline 13 MST & 53 & 49 & 102 & 20,6 & 40 & 3 \\
\hline 14 MST & 88 & 72 & 160 & 21,5 & 26 & 3 \\
\hline 15 MST & 49 & 41 & 90 & 21,9 & 50 & 4 \\
\hline 16 MST & 40 & 35 & 75 & 21 & 51 & 4 \\
\hline 17 MST & 59 & 37 & 96 & 21,7 & 67 & 5 \\
\hline 18 MST & 64 & 38 & 102 & 21,6 & 129 & 6 \\
\hline
\end{tabular}

Hasil pengamatan populasi lalat buah usia tanaman 7-18 MST semua menunjukan jumlah populasi lalat buah pada perangkap luar lebih dominan dibandingkan dengan hasil tangkapan lalat buah pada perangkap dalam. Namun, pada usia tanaman 7-9 MST memiliki selisih tangkapan yang cukup jauh antara perangkap luar dengan perangkap dalam (Tabel 1). Populasi lalat buah mulai menurun pada usia tanaman 11 MST dan tidak setinggi populasi pada 4 minggu awal pengamatan. Hal tersebut dikarenakan berakhirnya musim panen tanaman inang lain di sekitar lahan pengamatan.

Tingginya hasil tangkapan tersebut dikarenakan pengaruh sumber inang lain yang melimpah di sekitar lahan pengamatan, sehingga berpengaruh terhadap peningkatan hasil tangkapan. Hal tersebut sesuai dengan penelitian Ye \& Liu (2007) melaporkan bahwa periode pembuahan serta ketersediaan inang di lahan menjadi salah satu faktor yang mempengaruhi fluktuasi populasi lalat buah.

\section{Faktor Abiotik}

Tabel 2 memaparkan hasil analisis regresi dan korelasi fluktuasi populasi lalat buah terhadap faktor abiotik berupa suhu, curah hujan dan jumlah hari hujan pada pertanaman cabai merah. Hasil analisis tersebut memaparkan faktor abiotik menunjukan pengaruh yang tidak signifikan diduga karena wilayah tempat penelitian berlangsung merupakan lingkungan yang optimal bagi populasi lalat buah. Menurut Ye \& Liu (2005), suhu optimal bagi perkembangan lalat buah berada pada kisaran suhu $20^{\circ}-28^{\circ} \mathrm{C}$.
Tabel 2. Hubungan antara fluktuasi populasi lalat buah dengan faktor abiotik di Desa Pulosari Pangalengan.

\begin{tabular}{|c|c|c|c|c|c|}
\hline Faktor iklim & Persamaan Regresi & df & $\mathbf{R}^{2}$ & $\begin{array}{c}\text { Koefisien } \\
\text { Korelasi }\end{array}$ & $\mathbf{P}$ \\
\hline Suhu & $\mathrm{Y}=-101,2+2298,7 \mathrm{x}$ & 11 & 0,253 & 0,503 & 0,096 \\
\hline $\begin{array}{c}\text { Curah Hujan } \\
\begin{array}{c}\text { Jumlah Hari } \\
\text { Hujan }\end{array}\end{array}$ & $\mathrm{Y}=0,143+154,4 \mathrm{x}=6,607+140.51 \mathrm{x}$ & 11 & 0,004 & 0,064 & 0,842 \\
\hline $\begin{array}{c}\text { Keterangan: } \\
\text { Jf : Derajat Bebas }\end{array}$ & $\mathrm{R}^{2}$ : Koefesien Determinasi & Sig: Signifikansi & 0,709 \\
\hline
\end{tabular}

Tinggi rendahnya populasi lalat buah jantan yang tertangkap dalam perangkap metil eugenol serta kaitannya dengan suhu rata-rata mingguan di Pangalengan dapat dilihat pada Gambar 1 . Terjadinya fluktuasi suhu tiap minggunya menunjukan naik turunnya suhu dan sedikit berpengaruh terhadap fluktuasi populasi lalat buah saat tanaman berumur 7 MST sampai dengan 18 MSTDapat dilihat telah terjadi peningkatan jumlah populasi lalat buah di lokasi pengamatan pada saat suhu rata-rata $20^{\circ} \mathrm{C}$ saat tanaman berumur $7-10$ MST. Jumlah populasi tertinggi terjadi saat tanaman berumur 9 MST dengan rata-rata suhu mingguan $20,9^{\circ} \mathrm{C}$. Sedangkan jumlah populasi lalat buah terendah saat suhu rata-rata mingguan $21^{\circ} \mathrm{C}$. Keadaan tersebut dapat terjadi dikarenakan suhu yang optimum bagi lalat buah pada lokasi tersebut berada pada suhu rata-rata $20^{\circ} \mathrm{C}$ atau peningkatan populasi di awal pengamatan terjadi dikarenakan faktor lain berupa faktor inang lain yang pada saat itu jumlahnya cukup banyak. 


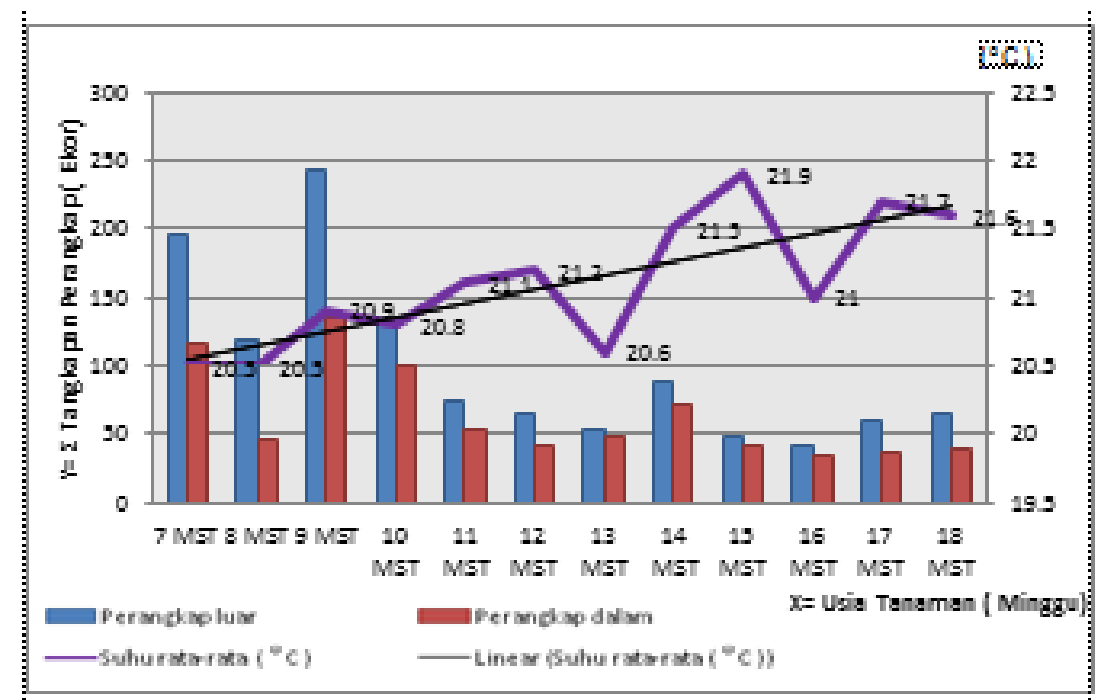

Gambar 1. Pengaruh suhu terhadap fluktuasi populasi lalat buah jantan.

Gambar 2 menujukkan tinggi rendahnya populasi lalat buah jantan yang tertangkap dalam perangkap serta kaitannya dengan curah hujan ratarata mingguan di lokasi pengamatan. Hasil analisis regresi pada penelitian ini, curah hujan tidak menunjukan pengaruh yang signifikan terhadap fluktuasi populasi lalat buah pada pertanaman cabai merah. Hal tersebut dapat terjadi akibat curah hujan yang terlalu tinggi menyebabkan terjadinya kegagalan pada saat proses pembentukan imago dari pupa di dalam tanah yang berakibat terjadinya penurunan populasi lalat buah.

Hasil persamaan regresi menunjukan pengaruh jumlah hari hujan menunjukan korelasi yang positif terhadap jumlah populasi lalat buah yang tertangkap dalam perangkap metil eugenol. Namun pengaruh jumlah hari hujan memiliki korelasi yang kecil terhadap populasi lalat buah (Gambar 3).

Tingginya curah hujan serta jumlah hari hujan dapat mengurangi presentasi keberhasilan pembentukan pupa menjdi imago lalat buah dewasa. Semakin tinggi jumlah hari hujan di lapangan maka semakin sedikit jumlah populasi lalat buah dikarenakan hujan yang terjadi di pagi ataupun siang hari dapat mengganggu aktivitas dan membatasi mobilitas lalat buah. Hal yang sama juga dilaporkan oleh Susanto (2010a) menyebutkan, frekuensi dan curah hujan yang tinggi dapat menghambat pembentukan pupa serta dapat menghambat mobilitas lalat buah dalam mencari makan dan bertelur sehingga populasi lalat buah yang didapatkan dalam perangkap menjadi sedikit.

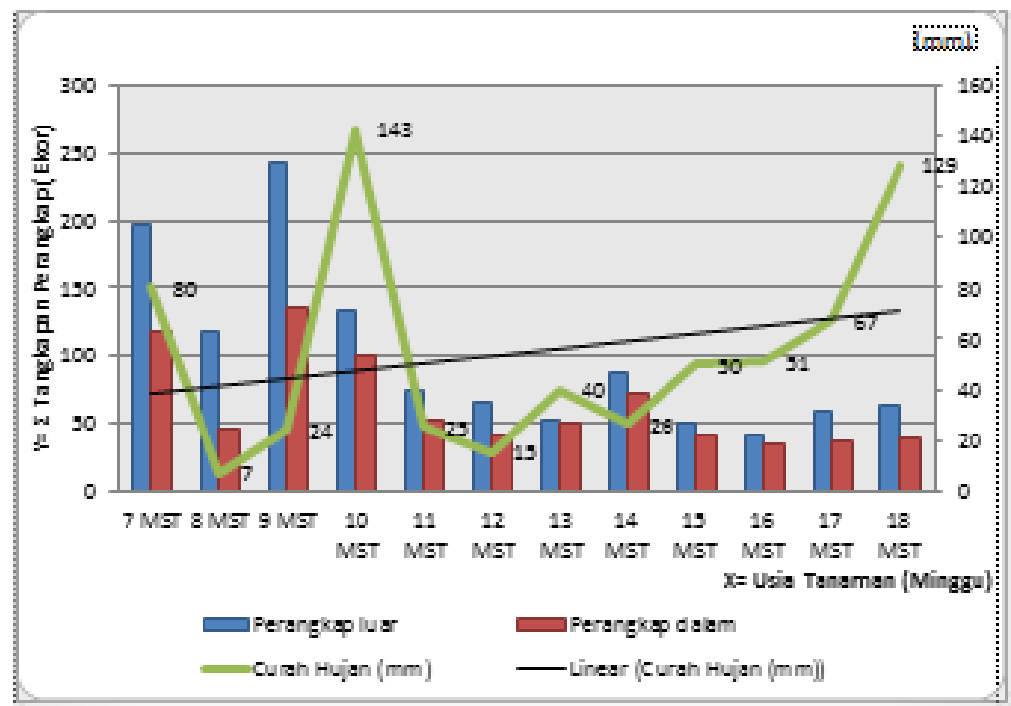

Gambar 2. Pengaruh curah hujan terhadap fluktuasi populasi lalat buah jantan 


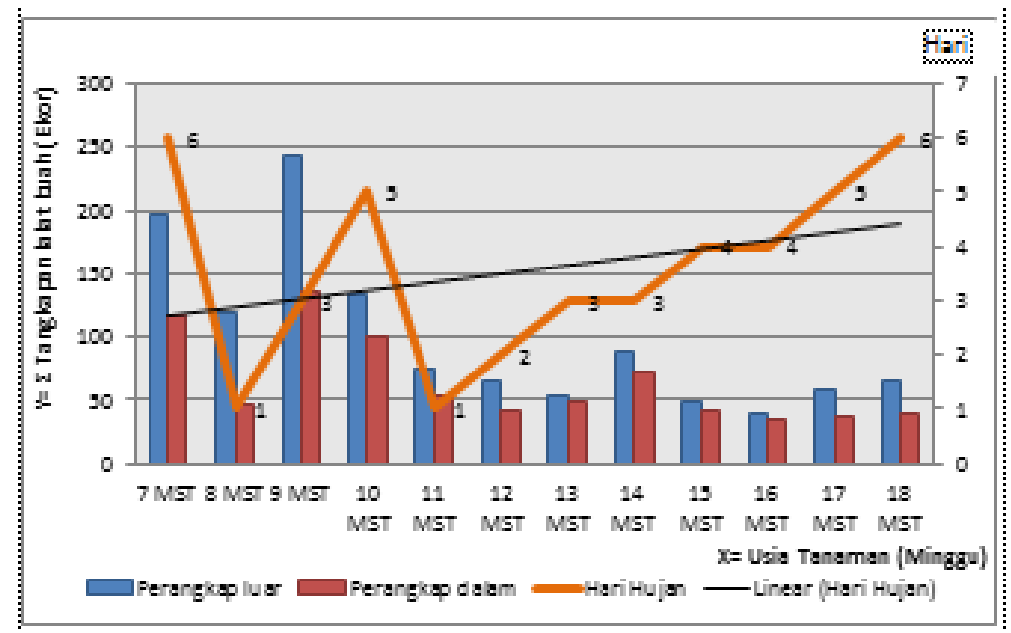

Gambar 3. Pengaruh jumlah hari hujan terhadap fluktuasi populasi lalat buah jantan.

\section{Faktor Biotik}

Faktor biotik merupakan faktor yang berpengaruh terhadap fluktuasi populasi lalat buah selain faktor lingkungan. Ketergantungan lalat buah terhadap ketersediaan makanan serta inang tempat meletakkan telurnya membuat faktor biotik sangat berperan dalam perkembangan populasi lalat buah pada habitatnya (Chen et al., 2006).

Hasil pengamatan fenologi tanaman inang cabai merah di pangalengan terlihat bahwa tingginya jumlah populasi lalat buah dilahan dimulai dari 4 minggu pengamatan awal diantara usia tanaman baru mencapai 7-10 MST. Sedangkan pada usia tersebut sebagian tanaman berada pada masa pembungaan dan pembentukan buah muda. Pada 4 minggu pengamatan awal, tingginya jumlah populasi lalat buah di lahan terjadi pada saat tanaman memasuki usia 9 MST yang merupakan berada pada fase generatif (Gambar 4).

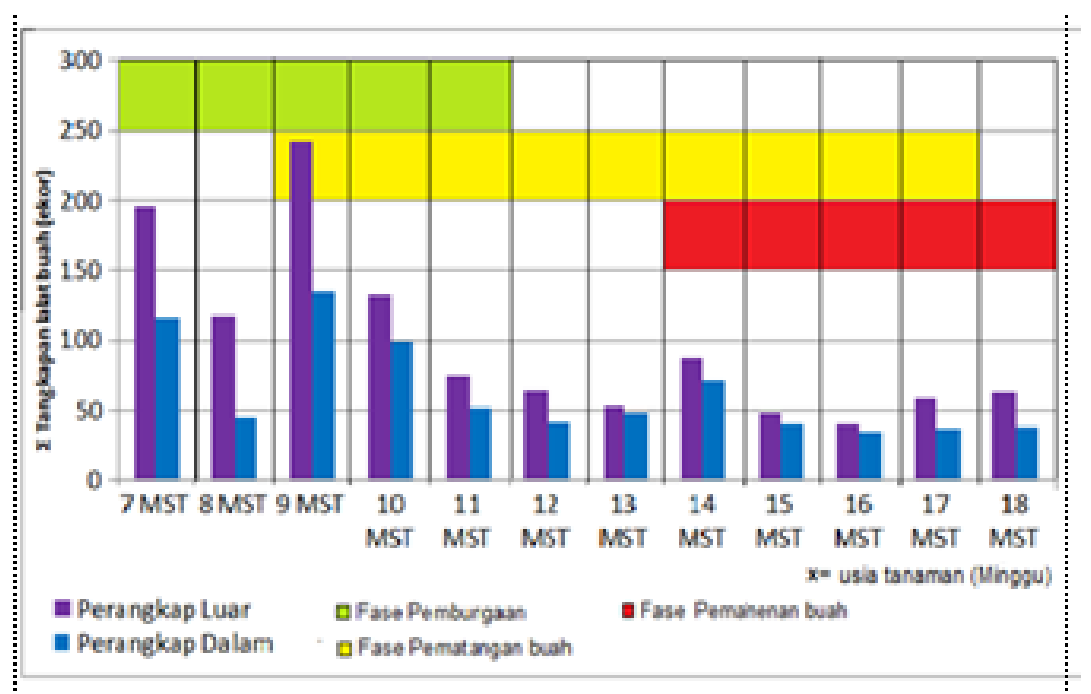

Gambar 4. Pengaruh jumlah hari hujan terhadap fluktuasi populasi lalat buah jantan.

Peningkatan jumlah populasi lalat buah terjadi pada tanaman usia 14 MST dimana tanaman mulai matang secara merata dan terjadi penurunan pada saat tanaman usia 15 MST dikarenakan pada waktu tersebut telah dilakukan pemanenan pertama. Dampak yang terjadi pada lalat buah akibat pemanenan buah cabai merah mempengaruhi penurunan jumlah populasi lalat buah dilahan karena sumber inang tempat meletakkan telur telah berkurang dan akan kembali meningkat lagi seiring dengan pematangan buah berikutnya.

Hasil pengamatan pada lahan pengamatan parasitoid yang ditemukan yang memarasit larva lalat buah pada tanaman cabai adalah adalah 
Psyttalia fijiensis (Fullaway) dan Opius sp. pengamatan parasitoid tersebut dilakukan dengan cara melihat hasil rearing dari cabai merah yang terserang larva lalat buah dan juga dengan menangkap langsung parasitoid yang terdapat di lokasi pada saat pengamatan sedang berlangsung. Kedua jenis parasitoid tersebut memarasit larva lalat buah yang telah dipilih oleh induk parasitoid kemudian dijadikan inang sebagai tempat meletakkan telur dan perkembangbiakan larvanya.

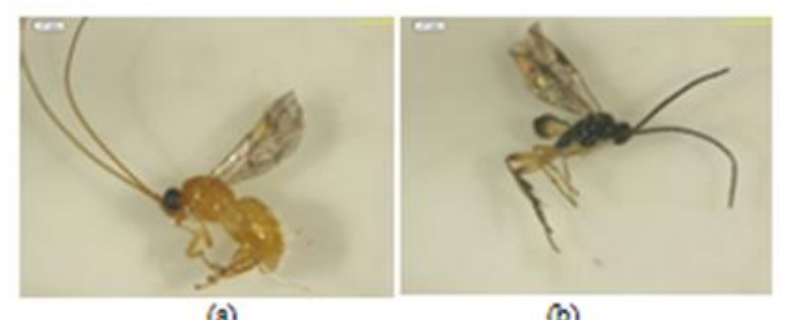

Gambar 5. Parasitoid yang memarasiti larva lalat buah pada tanaman cabai, Psyttalia fijiensis (a) dan Opius sp. (b).

Hasil pengamatan terhadap musuh alami berupa jenis serangga predator ditemukan pada lokasi penelitian pertanaman cabai merah yang berpotensi memangsa lalat buah seperti laba-laba, cocopet (Euborellia annulipes), semut (Dorylus sp.) dan belalang mantis (Creobacter sp.).

\section{Aktivitas Harian}

Aktivitas harian lalat buah berlangsung mulai pagi hingga sore hari sehingga pengamatan aktivitas harian lalat buah dilakukan mulai dari pukul 06.00 sampai dengan pukul 18.00 dan dilakukan pengamatan tiap 2 jam sekali sehingga dapat diketahui waktu yang optimum bagi lalat buah beraktivitas paling aktif (Tabel 3).

Tabel 3. Aktivitas harian lalat buah.

\begin{tabular}{c|c}
\hline Waktu Pengamatan & $\begin{array}{c}\text { Jumlah Lalat Buah Tertangliap } \\
\text { (Elior) }\end{array}$ \\
\hline $06.00-08.00$ & 0 \\
$08.00-10.00$ & 4 \\
$10.00-12.00$ & 5 \\
$12.00-14.00$ & 5 \\
$14.00-16.00$ & 2 \\
\hline $16.00-18.00$ & 0 \\
\hline Total Tangkapan & 16 \\
\hline
\end{tabular}

Aktivitas harian lalat buah pada pertanaman cabai merah memiliki waktu paling aktif bergerak pada pagi sampai dengan siang hari. Hal ini ditunjukan dari hasil pengamatan lapangan (Tabel 4.2) dimana waktu aktif lalat buah dengan populasi paling tinggi pada pukul 10.00 sampai dengan pukul
12.00 dan pukul 12.00 sampai dengan pukul 14.00 dengan jumlah populasi lalat buah yang tertangkap perangkap sebanyak 5 ekor. Hal tersebut dikarenakan pada pertanaman cabai merah, pada waktu pagi sampai dengan siang hari terjadi penyerbukan sehingga pada lahan banyak terdapat serbuk sari yaitu sebagai makanan lalat buah.

Manurung dan Emmi (2012), melaporkan bahwa rendahnya aktivitas yang di temukan di lahan pengamatan pada pagi hari pukul 06.00-08.00 dikarenakan perilaku lalat buah yang cenderung sensitif terhadap suhu lingkungan sehingga suhu ambang tubuhnya (threshold temperature) harus lebih terdahulu dilampaui agar dapat melakukan aktivitasnya seperti menggerakkan sayap, sungut, tungkai dan hingga akhirnya terbang mencari makan atau melakukan aktivitas seksual. Penurunan jumlah lalat buah yang beraktivitas pada pukul 16.00-18.00 dikarenakan pada saat pengamatan terjadi hujan yang cukup lama sehingga menghambat pergerakan lalat buah untuk beraktivitas.

\section{Identifikasi Spesies Lalat Buah}

Identifikasi dilakukan dengan cara mengukur dan membandingkan panjang aedeagus (alat kelamin lalat buah jantan) pada sampel spesimen lalat buah yang terperangkap. Pengidentifikasian spesimen lalat buah dengan mengukur aedeagus lalat buah jantan dilakukan karena lalat buah Bactrocera dorsalis Kompleks jantan sangat sulit membedakannya jika dilihat dari kasat mata dan hanya dapat dibedakan pada ukuran aedeagus sedangkan pengukuran pada cell $\mathrm{dm}$ dilakukan untuk mengetahui rasio panjang cell $d m$ pada sayap dengan panjang aedeagus (Susanto, 2010a). (Gambar 6).



(a)

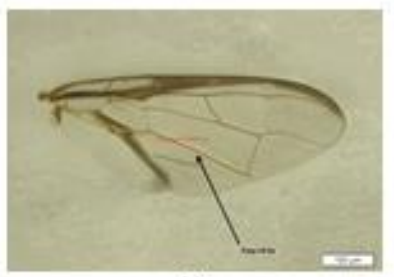

(b)
Gambar 6. Identifikasi spesies lalat buah secara morfologi dengan membandingkan aedeagus (a) dan pengukuran cell $\mathrm{dm}$ pada sayap (b).

Hasil percobaan ditunjukan dari 100 sampel spesimen lalat buah pada pertanaman cabai merah yang teridentifikasi, didapatkan spesies Bactrocera 
dorsalis dengan jumlah populasi sebanyak 93\% dari sampel spesimen sedangkan jumlah spesies Bactrocera carambolae yang teridentifikasi sebanyak $7 \%$ dari sampel keseluruhan. Ukuran aedeagus dari masing-masing spesies yang teridentifikasi memiliki panjang yang berbeda-beda. Pada $B$. dorsalis yang menyerang tanaman cabai merah pada lokasi pengamatan memiliki panjang berkisar antara 2,71 $3,17 \mathrm{~mm}$ sedangkan B. carambolae yang teridentifikasi memiliki panjang aedeagus berkisar antara 2,44-2,61 mm.

Pengidentifikasian panjang aedeagus pada Bactrocera dorsalis Kompleks tersebut dilakukan sesuai dengan penelitian Iwahashi (1999) yang menyatakan bahwa panjang aedeagus pada lalat buah jantan yang memiliki ukuran aedeagus berkisar 2,39 - 2,68 mm termasuk kedalam spesies $B$. carambolae sedangkan pada spesies $B$. dorsalis memiliki panjang aedeagus antara 2,66-3,34 mm.

\section{SIMPULAN}

1. Faktor abiotik tidak memberikan pengaruh yang signifikan terhadap fluktuasi populasi lalat buah pada pertanaman cabai merah ditunjukan dengan analisis regresi masing-masing pada suhu ( $\left.Y=-101,2+2298,7 x ; R^{2}=0,253 ; P>0,05\right)$,

2. Curah hujan $\left(\mathrm{Y}=0,143+154,4 \mathrm{x} ; \mathrm{R}^{2=} 0.004 ; \mathrm{P}>\right.$ $0,05)$, dan Jumlah hari hujan $(\mathrm{Y}=6,607+$ $\left.140,51 \mathrm{x} ; \mathrm{R}^{2}=0,015 ; \mathrm{P}>0,05\right)$ sehingga fluktuasi populasi lalat buah pada pertanaman cabai merah lebih dipengaruhi faktor biotik berupa fenologi inang dan peran musuh alami (predator dan parasitoid).

3. Lalat buah yang memiliki populasi paling dominan pada pertanaman cabai merah di Pangalengan adalah Bactrocera dorsalis yang termasuk sibling dari spesies Bactrocera dorsalis Kompleks dengan jumlah populasi sebanyak 93\% dari sampel spesimen.

\section{DAFTAR PUSTAKA}

Allwood AJ. 1997. Biology and ecology: prerequisites for understanding and managing fruit flies (Diptera: Tephritidae). ACIAR Proceedings; Nadi. Fiji 28-31 Oktober 1996.

Anonim. 2009. Standart Operating Procedure (SOP) budidaya cabai merah Gunung Kidul. Dinas Pertanian. Jogjakarta.
Anonim. 2011. Desa Pulosari. Tinjauan Pustaka. Tesis. Fakultas Pertanian Universitas. Padjadjaran. Bandung.

Bateman, MA. 1972. The ecology of fruit flies. Annu. Rev.Entomol. 17.

Chen CC, YJ Dong, CT Lie, KY Lin and LL Cheng. 2006. Movement of the oriental fruit fly, Bactrocera dorsalis (Hendel) (Diptera: Tephritidae) in a Guava orchard with special reference to its population changes. Formosan Entomol. 26.

Gaspersz, V. 1991. Metode Perancangan Percobaan . Armico. Bandung .

Ginting R. 2009. Keanekaragaman lalat buah (Diptera: Tephritidae) di Jakarta.Depok. dan Bogor sebagai bahan kajian penyusunan analisis resiko hama.[Tesis]. Bogor: Fakultas Pertanian. Institut Pertanian Bogor.

Herlinda, S, Zuroaidah, Y Pujiastuti, S Samad dan T Adam. 2008. Spesies lalat buah yang menyerang sayuran Solanaceae dan Cucurbitaceae di Sumatera Selatan. Jurnal Hortikultura 18(2) : 212-220.

Iwahashi, O. 1999. Distinguishing between two sympatric scpecies Bactrocera papayae and Bactrocera carambolae (Diptera: Tephritidae) based on aedeagal length. Annnalas of The Entomological Society of America 92 (5): 639-643.

Kalshoven, LGE. 1981. The Pest of Crops in Indonesia. PT Ichtiar Baru - van Hoeve, Jakarta $301 \mathrm{p}$.

Manurung, B, P Puji, dan ET Emmi. 2012. Pola aktivitas harian dan dinamika populasi lalat buah Bactrocera dorsalis complex pada pertanaman jeruk di dataran tinggi Kabupaten Karo, Provinsi Sumatra Utara. J. HPT Tropika 12 (2): 103-110.

Patty, A. 2012. Efektivitas metil eugenol terhadap tangkapan lalat buah (Bactrocera dorsalis) pada pertanaman cabai. Agrologia, Vol.1, No. 1, April 2012.

Piay, S, A Tyasdjadja, Y Ermawati, dan R Hantoro. 2010. Budidaya dan Pascapanen Cabai Merah (Capsicum annuum L). Badan Penelitian dan Pengembangan Pertanian Balai Pengkajian Teknologi Pertanian. Jawa Tengah.

Sunarno. 2011. Ketertarikan serangga lalat buah terhadap berbagai papan perangkap berwarna sebagai salah satu teknik pengendalian. Jurnal Agroforestri 6 (2): 129-134. 
Susanto, A. 2010a. Estimasi dan Dinamika Populasi Lalat Buah, Bactrocera dorsalis Kompleks (Diptera: Tephitidae) Pada Pertanaman Mangga. Disertasi. Institut Teknologi Bandung. Bandung.

Susanto, A. 2010b. Pengendalian lalat buah yang ramah lingkungan. Fakultas Pertanian universitas Padjadjaran. Bandung. Diakses 24 Oktober 2013 melalui:http://pustaka.unpad.ac.id/wpconte nt/uploads/2010/05/pengendalian_lalat_bua h_yang_ramah_lingkungan 1.pdf

Siwi, SS. 2005. Eko-biologi Hama Lalat Buah. BBBiogen. Bogor.

Wardani \& Purwanta. 2008. Teknologi Budidaya Cabai Merah. Balai Besar Pengembangan Teknologi Pertanian. Litbang. Lampung.
White, IM, and M Elson-Harris. 1992. Fruit Flies of Economic Importence: Their Identification and bionomics. CABInternational. Oxon, UK. 601 pp.

Ye, H. 2001. Distribution of the oriental fruit fly (Diptera:Tephritidae) in Yunnan province. Entomologia Sinica. 8(2): 175-182.

Ye, H, and JH Liu. 2005. Population dynamics of the oriental fruit fly, Bactrocera dorsalis (Diptera: Tephritidae) in the Kunming area, southwestern China. Insect Science 12 (5): 387-392.

Ye, $\mathrm{H}$, and $\mathrm{JH}$ Liu. 2007. Population dynamics of oriental fruit fly Bactrocera dorsalis (Diptera: Tephritidae) in Xishuangbanna, Yunnan Province, China. Frontiers in Agriculture of China 1(1): 76-80. 